\title{
COVID-19 Creating another problem? Sustainable solution for PPE disposal through LCA approach
}

\author{
Harender Kumar ${ }^{1} \cdot$ Amaanuddin Azad $^{1} \cdot$ Ankit Gupta $^{1,2} \cdot$ Jitendra Sharma ${ }^{3}$. \\ Hemant Bherwani ${ }^{1,2}$ (D) Nitin Kumar Labhsetwar ${ }^{1,2} \cdot$ Rakesh Kumar $^{1,2}$
}

Received: 4 July 2020 / Accepted: 30 September 2020 / Published online: 9 October 2020

(c) Springer Nature B.V. 2020

\begin{abstract}
Amid COVID-19, there have been rampant increase in the use of Personal Protective Equipment (PPE) kits by frontline health and sanitation communities, to reduce the likelihoods of infections. The used PPE kits, potentially being infectious, pose a threat to human health, terrestrial, and marine ecosystems, if not scientifically handled and disposed. However, with stressed resources on treatment facilities and lack of training to the health and sanitation workers, it becomes vital to vet different options for PPE kits disposal, to promote environmentally sound management of waste. Given the various technology options available for treatment and disposal of COVID-19 patients waste, Life Cycle Assessment, i.e., cradle to grave analysis of PPE provides essential guidance in identifying the environmentally sound alternatives. In the present work, Life Cycle Assessment of PPE kits has been performed using $\mathrm{GaBi}$ version 8.7 under two disposal scenarios, namely landfill and incineration (both centralized and decentralized) for six environmental impact categories covering overall impacts on both terrestrial and marine ecosystems, which includes Global Warming Potential (GWP), Human Toxicity Potential (HTP), Eutrophication Potential (EP), Acidification Potential (AP), Freshwater Aquatic Ecotoxicity Potential (FAETP) and Photochemical Ozone Depletion Potential (POCP). Considering the inventories of PPE kits, disposal of PPE bodysuit has the maximum impact, followed by gloves and goggles, in terms of GWP. The use of metal strips in face-mask has shown the most significant HTP impact. The incineration process (centralized-3816 kg CO2 eq. and decentralized-3813 kg CO2 eq.) showed high GWP but significantly reduced impact w.r.t. AP, EP, FAETP, POCP and HTP, when compared to disposal in a landfill, resulting in the high overall impact of landfill disposal compared to incineration. The decentralized incineration has emerged as environmentally sound management option compared to centralized incinerator among all the impact categories, also the environmental impact by transportation is significant (2.76 kg CO2 eq.) and cannot be neglected for long-distance transportation. Present findings can help the regulatory authority to delineate action steps for safe disposal of PPE kits.
\end{abstract}

Keyword Life cycle assessment (LCA) · Personal protective equipment (PPE) · COVID19 - Landfill · Incineration

Hemant Bherwani

h.bherwani@neeri.res.in

Extended author information available on the last page of the article 


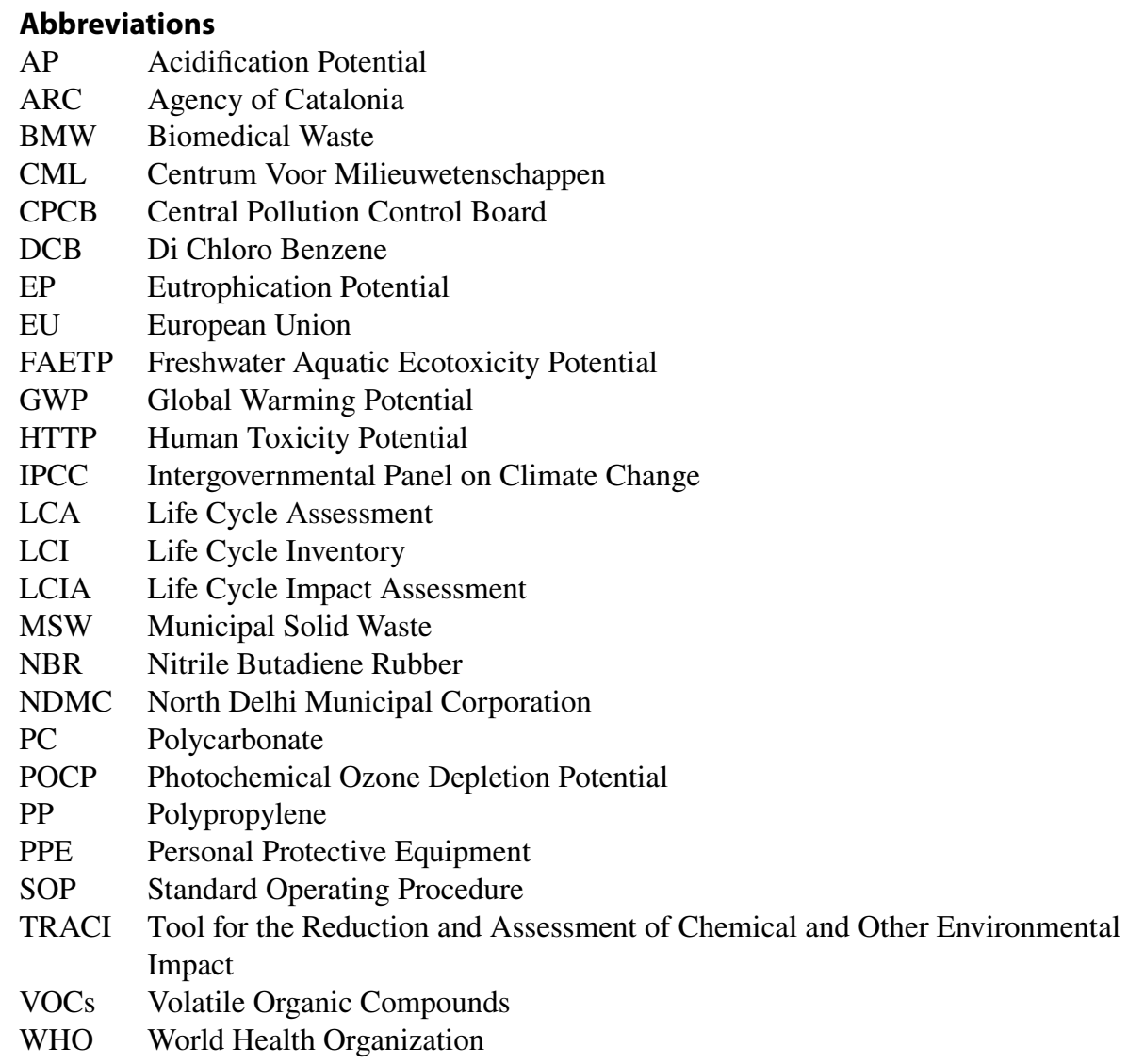

\section{Introduction}

In December 2019, a pneumonia type outbreak was reported in Wuhan, China (New York Times 2020) which was traced to a novel strain of coronavirus (WHO 2020a). During January 2020 WHO declared Coronavirus disease (COVID-19) as a pandemic disease (WHO 2020b), which spread very rapidly from human to human by personal contact, contact with air-water droplets during sneezing, and coughing of coronavirus affected person (Bherwani et al. 2020a; Nair et al. 2020; Wathore et al. 2020; Gupta et al. 2020). As of 14 June 2020, there have been at least 4, 30,139 confirmed deaths, and more than 77, 87,271 (COVID-19 Dashboard CSSE) confirmed cases under COVID-19 pandemic. Since to date, there is no vaccine identified yet (WHO 2020a, b, c, d, e; Healthline 2020) for the effective prevention of COVID-19 disease, thus other measures recommended by WHO to mitigate the spread of COVID-19 (WHO 2020c) become very vital for peoples among this pandemic (Kaur et. al. 2020).

The adverse impacts of COVID-19 on human and planetary health will arise from different sources during the response (UNEP 2020). As per a WHO estimate, 89 million medical mask, 76 million examination gloves and 1.6 million goggles are required for the COVID-19 response each month (WHO 2020e) for which the manufacturing capacity should ramp by $40 \%$, to meet the rising global demand (Park et al. 2020). With reported 
cases of COVID-19 infected health and sanitation workers (Satheesh 2020; Hindustan times 2020; New India Express 2020), waste management of used infectious safety gears has become a critical component to restrict the spread of novel coronavirus (Bherwani et al. 2020b; Vanapalli et al. 2020). According to WWF report (Italy WWF 2020), "If only $1 \%$ of the masks were disposed of incorrectly and perhaps dispersed in nature, would result in 100 million masks per month in the environment".

Across the globe, an unprecedented rise in the COVID-19 cases, the amount of waste of infectious waste generated, far exceeds the available capacity for treatment. Worldwide waste management systems have already been unable to deal with existing waste satisfactorily, the imminent surge in the volume of waste from COVID-19 pandemic threatens to overwhelm existing waste management systems as do healthcare capacity. The directives from WHO, which mandate incineration of PPEs and other infectious wastes, especially made from plastic, has increased the load on the incineration facilities (WHO 2017a, b). In China, with $370 \%$ rise in Hubei province and with $600 \%$ rise in Wuhan, i.e., from a normal level to $40 \mathrm{t} /$ day to about a peak $240 \mathrm{t} /$ day, exceeding the maximum incineration capacity available with the country (Jiri et al. 2020; Ivy S. 2020; Klemeš et al. 2020). Similar, the Waste Agency of Catalonia (ARC), Spain, has noticed a 350\% increase in medical waste with added 925 tons/month more than usual (ACR 2020). In the USA, a multi-fold increase in from PPEs has been reported (Justine 2020). In India, Gurugram city has seen two times increase in the quantity of COVID-19 related BMW with a prediction of over a ton of COVID-19 related BMW every day (Prayag 2020). The North Delhi Municipal Corporation (NDMC), India, has also observed an additional 11.4 tons of hazardous waste from households (Abhimanyu C. 2020), and Ahmedabad's Apollo hospital gave reported a 1.5 fold increase in BMW in comparison to normal of 100-120 kg per day (Yahoo 2020).

The effective management of coronavirus infectious waste, including PPEs, has been identified by as a key area of concern by regulatory agencies in India, with the release of waste handling-treatment-disposal guidelines generated during treatment-diagnosis-quarantine of COVID-19 patients (CPCB Revision 2020; Aggarwal 2020). Unlike India, other countries like EU member countries have made changes in waste management in the context of the coronavirus crisis (Virjinijus S. 2020). Some European municipalities have suspended the plastic recycling industry with the fear that workers getting infected as the virus remains on the surface of waste bags and materials when they are collected (Zero Waste 2020a; Zero Waste 2020b)

The use of Personal Protective Equipment (PPE) has emerged as the most reliable and visible preventive control safety gear to keep the COVID-19 transmission at bay (Herron et al. 2020). Typical PPEs, also referred as PPE kits, are made of over $50 \%$ plastics (which takes up to 500 years to degrade) like PP, PC, and PVC, etc., includes surgical face mask with metal strip, gloves, goggles, full-body suits containing pant, gown with head cover and shoe cover (Park et al. 2020). National Disaster Management \& Safety protocols have advised the use of PPEs, by attending physicians and all the healthcare- nursing staff, funeral workers including visiting families etc., who are directly or indirectly in contact of any COVID-19 (confirmed or suspected) patients (Selvakumar et al. 2020; WHO 2020d; NMPA 2020). In the wake of necessary preventive control measures, it is evident that the used PPEs waste is likely to increase multiple folds and will stress the current waste management systems, and now pose a grave threat to the environment, if not tackled properly (ICT 2008).

In developing countries, with lack of complete connectivity and waste handling capacities in existing Centralized Bio-medical Waste Treatment Facilities (CBMWTF), the COVID19 infectious waste handling has become a grave concern (Henam and Shrivastav 2019; 
WHO 2017a, b; CPCB 2017). In India, practical implementation of effective COVID-19 waste management guidelines, with multiple cares at each step, including containers/bins/ trolleys be disinfected daily, use of double-layered bags (using 2 bags) of collection, regular sanitization of workers, and vehicle sanitization etc. (CPCB 2020; Aggarwal 2020) becomes looming and challenging. In populous countries like India of 138 crore people (Worldometer 2020) and having fifth-highest number of confirmed cases in the world (The Guardian 2020), with overcrowded hospitals, large cities only connected to CBMWTF and lack of training of health workers (WHO 2017a, b) and having institutional and residential quarantine centre's staff, adds to the challenges. There have been reports of dumping of masks and medical waste, leading to unknowing containmination of workers with coronavirus from various cities of India (Abhimanyu C. 2020; The New York Times 2020). Hence, in consideration with the above, it becomes essentially important to explore and encourage decentralized disposal techniques, with treatment and disposal at source, of effective waste management, considering handling, storage and transportation-related risks.

From Table 1, it can be inferred that majority of the previous research works focused on the alternatives to use and reuse PPEs and to minimize its requirement as well as waste generation through methods like disinfection by ultraviolet rays or treating used PPEs with hydrogen peroxide. But these studies lacked in considering other vital environmental impact parameters, during manufacturing and disposal of PPEs waste to the environment. The current research focused on the cradle to grave analysis of PPEs for environmentally sound and sustainable management of these wastes, which has not been reported till date. Thus, our present study on Life Cycle Assessment of PPEs for disposal of infectious PPE waste becomes very vital for environmentally sound management of PPE waste.

The present work has tried to evaluate different disposal options for PPE kits, i.e., landfill, centralized incinerator and decentralized incinerator, with a view to promote environmentally sound management of waste. The study entails an assessment of all the life cycle stages including raw material extraction, material processing, production, use, disposal of PPE kits, using Life Cycle Assessment (LCA) tools, with an idea to transform the country's waste management sector into a secondary resource recovery sector, coupled with its integration with the manufacturing sector, to implement and promote a circular economy and ecosystem services conservation approach through a life cycle approach (Bherwani et al. 2020c; Draft NERP 2019).

\section{Methodology}

LCA is defined as "a tool to assess the potential environmental impacts and resources used throughout a product's life cycle, i.e., from raw material acquisition, via production and use stages, to waste management" (ISO 2006). LCA enables the estimation of the cumulative and realistic environmental impacts resulting from all the stages of a product life cycle, while also including impacts which are sometimes not included in the conventional analysis. In the current research, LCA is conducted according to the ISO 14,040 and ISO 14,044 standards.

\subsection{Goal and scope of the study}

The main goal of this study is to evaluate the relative human health and environmental impacts caused by raw material extraction, production, use, and disposal of PPE kit. Amid 


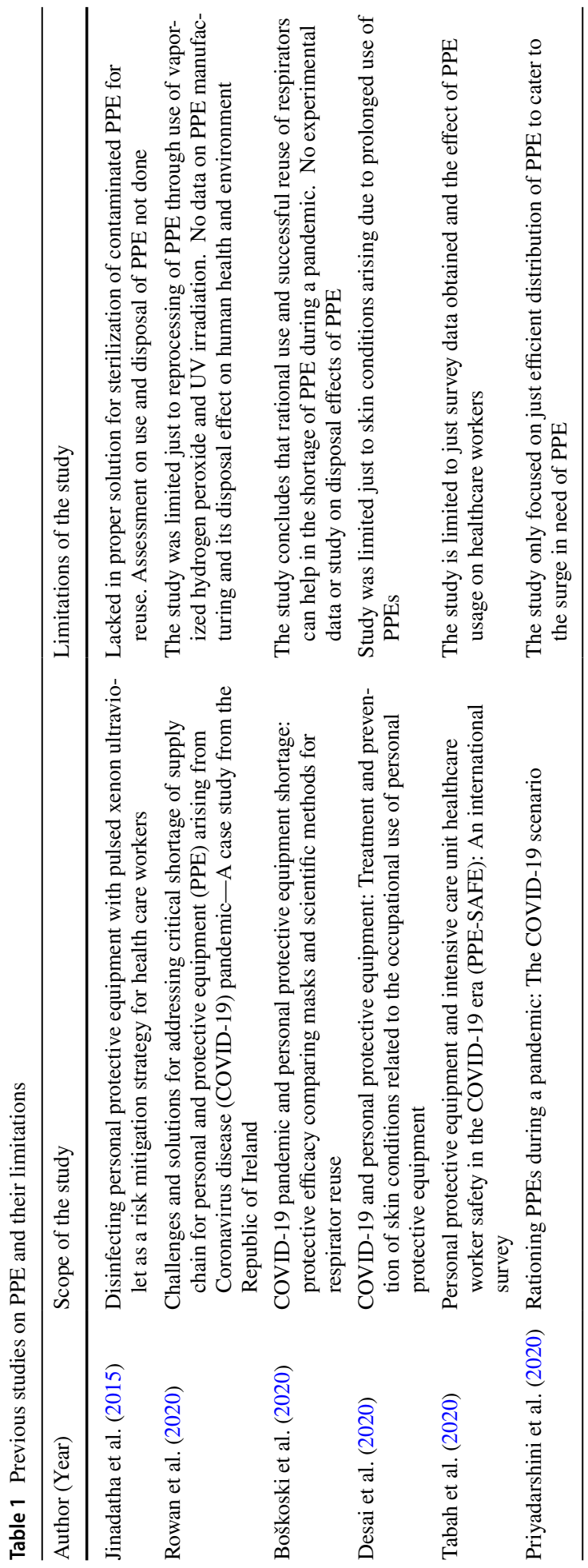


COVID-19 pandemic, there is a surge in demand for PPEs hence it is important to understand the impacts generated by PPEs along its life cycle.

The analysis is done in the form of three case studies namely Case-I, Case-II, and CaseIII as shown in Fig. 1, based on disposal options.

- Case-I: centralized incineration waste management system refers to the system in which the common facility of waste treatment is considered. The waste is collected from the source of waste generation and is transported to the waste disposal site with the help of compacted trucks. The distance from Nagpur city to Bhandewadi yard, site for waste disposal is $10 \mathrm{~km}$, and therefore, this distance has been taken for centralized system analysis (Arcadis 2017).

- CASE-II: A decentralized incineration waste management system is about each community managing and processing their waste in their locality and not sending it to a centralized large processing facility or often landfill (Agrawal and Jadon 2018.

- Case-III: Comprising of landfill disposal technique for PPE. The three case studies are so designed to estimate, compare, and evaluate the environmental and health impacts caused by the transportation activity as well as by landfill and incineration process.

\subsection{Functional unit}

The functional unit refers to a quantified description of the primary function of the system under study. The functional unit adopted for this study is the 1 ton of PPE kit (Babu et al. 2014). The PPE kit comprised of the goggles, gloves, shoe cover, mask, and overall suit, comprising of gown and pant. All the above-mentioned components of the PPE kit were precisely measured and weighed with the help of a weighing balance. All the items of the disposable PPE kit were one-time use only except goggles, which can be reused for 6 days (MoHFW). The reusability of goggles has been taken in this study as well (MoHFW 2020) after following proper precaution and disinfection guidelines as stated by the World Health Organization (WHO Guidelines 2020). Figure 2 gives details about the PPE kits configuration and composition. The material that comprises of these products were identified primarily based on manufacturer specification and through peer-reviewed literature (Marcin 2013; Seemal et al. 2020; Halyard; PAHO 2020; The conversation 2020).

\begin{tabular}{|c|c|c|c|}
\hline & $\begin{array}{c}\text { CASE I } \\
\text { Centralized Incineration }\end{array}$ & $\begin{array}{c}\text { Case II } \\
\text { Decentralized Incineration }\end{array}$ & $\begin{array}{l}\text { Case III } \\
\text { Landfill }\end{array}$ \\
\hline Footprint & $\begin{array}{l}\text { Includes transportation and } \\
\text { collection }\end{array}$ & $\begin{array}{l}\text { Transportation not } \\
\text { included, as disposal of } \\
\text { waste at its source itself }\end{array}$ & $\begin{array}{l}\text { Long distance transport } \\
\text { included }\end{array}$ \\
\hline Pollution & $\begin{array}{l}\text { Production of bottom ash } \\
\text { and emissions to air, water } \\
\text { and soil }\end{array}$ & $\begin{array}{l}\text { Production of bottom ash } \\
\text { and emissions to air, water } \\
\text { and soil }\end{array}$ & $\begin{array}{l}\text { Large potential for ground } \\
\text { water contamination }\end{array}$ \\
\hline Flexibility & $\begin{array}{l}\text { Need dedicated sites for } \\
\text { hazardous wastes treatment }\end{array}$ & $\begin{array}{l}\text { Need less space as } \\
\text { compared to large } \\
\text { incineration plants }\end{array}$ & $\begin{array}{l}\text { Requires quite large area } \\
\text { sites for hazardous wastes } \\
\text { treatment/landfilling }\end{array}$ \\
\hline Energy/Cost & $\begin{array}{l}\text { The heat produced is used } \\
\text { for steam generation and } \\
\text { energy recovery. }\end{array}$ & Low treatment cost & $\begin{array}{l}\text { Biogas capture for energy } \\
\text { recovery }\end{array}$ \\
\hline
\end{tabular}

Fig. 1 Illustration of three case studies based on disposal of PPEs 


\begin{tabular}{|c|c|c|c|}
\hline & Components & $\begin{array}{c}\text { Material Used } \\
\text { (Source: Jachowicz 2013) }\end{array}$ & Weight (\%) \\
\hline \multirow{2}{*}{ Surgical Face Mask } & Face Mask & Polypropylene (PP) Fabric & \multirow{2}{*}{$2 \%$} \\
\hline & Metal Strip & Aluminum Metal & \\
\hline Gloves & -- & Nitrile Butadiene Rubber (NBR) & $4 \%$ \\
\hline Goggles & -- & Polycarbonate (PC) & $10 \%$ \\
\hline \multirow{3}{*}{ PPE Suit } & Pant & \multirow{3}{*}{ Polypropylene (PP) fabric } & \multirow{3}{*}{$84 \%$} \\
\hline & Gown (with headcover) & & \\
\hline & Shoe Cover & & \\
\hline
\end{tabular}

Fig. 2 PPE kits classification and composition

\subsection{System boundaries}

The system boundary is the set of criteria specifying which activities are part of the studied system and which resource use and emissions associated with them are included in the study. The system boundary of the LCA study includes all direct and indirect resources use and emissions, like manufacturing, suppliers, along with the use and endof-life phase. In this study, materials like polypropylene (PP), nitrile butadiene rubber (NBR), polycarbonate (PC), and metal strip used in the manufacturing of PPE kit were included in the system boundary. Also, the use of PPE by frontline workers, vehicles used in transportation, and PPE disposal are also incorporated under the system boundary as shown in Fig. 3 Environmental impacts are calculated in terms of GWP $\left(\mathrm{kg} \mathrm{CO}_{2}\right.$ equivalent), AP ( $\mathrm{kg} \mathrm{SO}_{2}$ equivalent), $\mathrm{EP}$ ( $\mathrm{kg} \mathrm{PO}_{4}$ equivalent), HTTP ( $\mathrm{kg}$ DCB equivalent), FAETP (kg DCB equivalent) and POCP ( $\mathrm{kg}$ ethane equivalent).

\subsection{Life cycle inventory}

The life cycle inventory (LCI) model aims to link all unit processes that are required to deliver the product studies in an LCA. In the current study, all flows of the materials, energy, and all the waste streams related to the functional unit were identified and quantified.

\subsection{Environmental impact categories}

The study focused on the total impact caused by the PPE kit from their process of "cradle to grave". The impact categories are selected in a way that laid more emphasis on the environment and human health. Since there were only a few inventories contributing to other impacts, they are not considered in this study. The six impact categories chosen for this study are mainly Global Warming Potential (GWP), Human Toxicity Potential (HTP), Acidification Potential (AP) Eutrophication Potential (EP), Freshwater Aquatic Ecotoxicity Potential (FAETP), and Photochemical Ozone Creation Potential (POCP) (Rejane et al. 2019). The emission from the incineration process may give negative values due to 


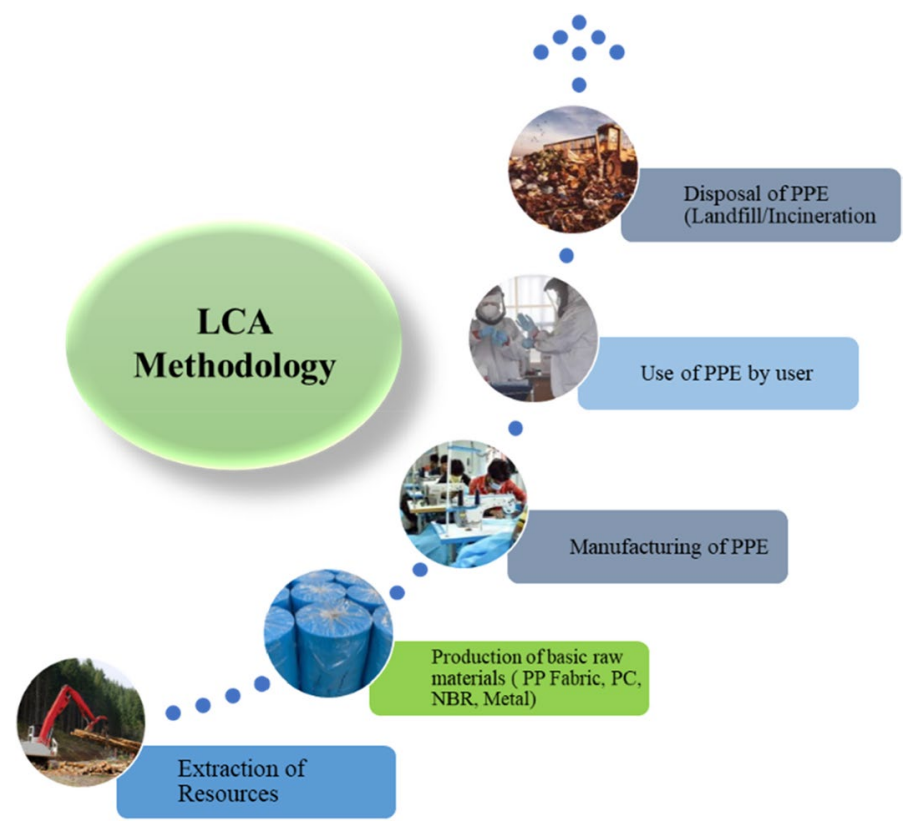

Fig. 3 An illustration of the LCA of PPE kit

application of heat recovery systems (Jeswani et al. 2016; Parkes et al. 2015). While conducting LCA, material wise.

\section{Results and discussion}

\subsection{Inventory results}

After running LCA in $\mathrm{GaBi}$, the inventory results were analyzed for the PPE kit. The inventory analysis for this study was based on Centrum voor Milieuwetenschappen (CML 2001-Jan. 2016) methods. The CML method is one of the strongly preferred methods followed by EDIP and Ecoindicator99 (Hand Book of Life Cycle Assessment 2018). It focuses on a series of environmental impact categories expressed in terms of emissions to the environment or resource use. The CML method groups the result into midpoint categories (Klemeš et al. 2020), the CML impact category used in this study were: GWP, HTP, EP, A.P, FAETP, and POCP.

The impact assessment of the Case-I revealed that the highest GWP impact was caused by PPE suit among all the inventories, with a total of $3,816.06 \mathrm{~kg} \mathrm{CO}_{2}$ eq. emission. The PPE suit is made of PP fabric resulting in emission during the manufacturing with a total of $1850 \mathrm{~kg} \mathrm{CO}$ eq, and additional emissions of $\mathrm{CO}_{2}$ eq were observed through masks. The details of the impact profiles are shown in Fig. 4. $1487.37 \mathrm{~kg} \mathrm{CO}_{2}$ eq. emission occurred during the incineration process of PPEs which contributed as the second-highest GWP related emissions. The GWP impact was from gloves with a total of $169.29 \mathrm{~kg} \mathrm{CO}_{2}$ eq. emission. The details reveal that manufacturing of gloves resulted in more GWP, due to a large amount 


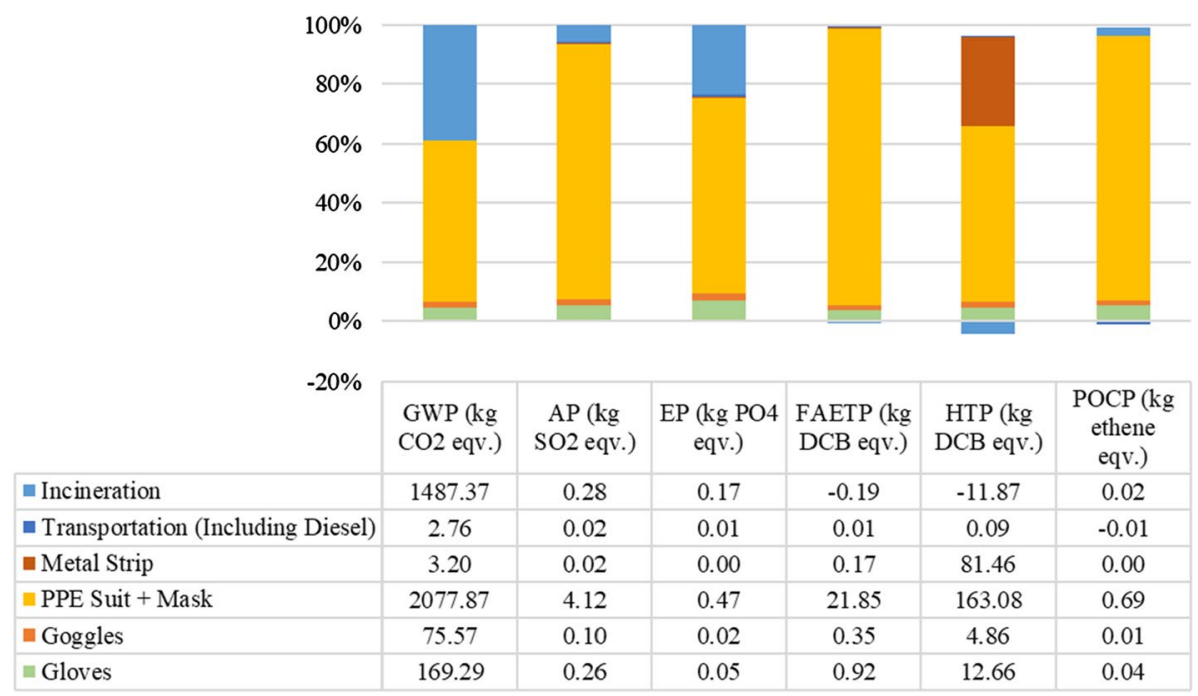

Fig. 4 LCA results for Case-I, Cradle to Grave with Centralized Incineration

of energy being consumed during its steam cracking process (Design Life Cycle 2018). The transportation by trucks for a payload of 1 ton PPE waste and $10 \mathrm{~km}$ travel to a disposal site, resulted in total GWP impact of $2.76 \mathrm{~kg} \mathrm{CO}_{2}$ eq, which is inclusive of diesel mix at the refinery. The HTP, FAETP, and AP values are also reported to be very high for PPE Suit and Mask, while negative values for incineration were observed probably due to heat recovery.

Case II results are similar to case I result, except for transportation. While most of the values are same, it is to be noted that impact categories values have reduced due to reduced transportation. The benefit may seem to be minuscule for the considered case; however, the large-scale operations lead to evident differences and reduced environmental and health footprint. The results are showcased in Fig. 5. The reduced transportation is also better due to multiple reasons other than reduced LCA-related impacts. The number of direct and indirect people handling also reduces significantly, which reduces fatalities and morbidities.

Case III is analyzed with respect to cradle to grave boundaries, with grave being the landfilling of the PPE. It can be seen from Fig. 6, the impact categories have shown a drastic increase except for GWP, which is lower due to the reduced amount of heat input in the disposal process.

In case III, transportation is also included till the landfill site. The values of EP, FAETP, HTP and POCP are higher than cases I and II, while AP values seem to remain constant across all the cases. It is worthwhile to note that there is no negative value for Landfill cases except for transportation POCP, which is negligible.

\section{Conclusion}

At present, the whole worlds are fighting a war against COVID-19 with countries implementing various measures to ensure reduced fatalities and morbidity from this novel coronavirus SARS-CoV-2. While this battle is being fought against a micro-sized 


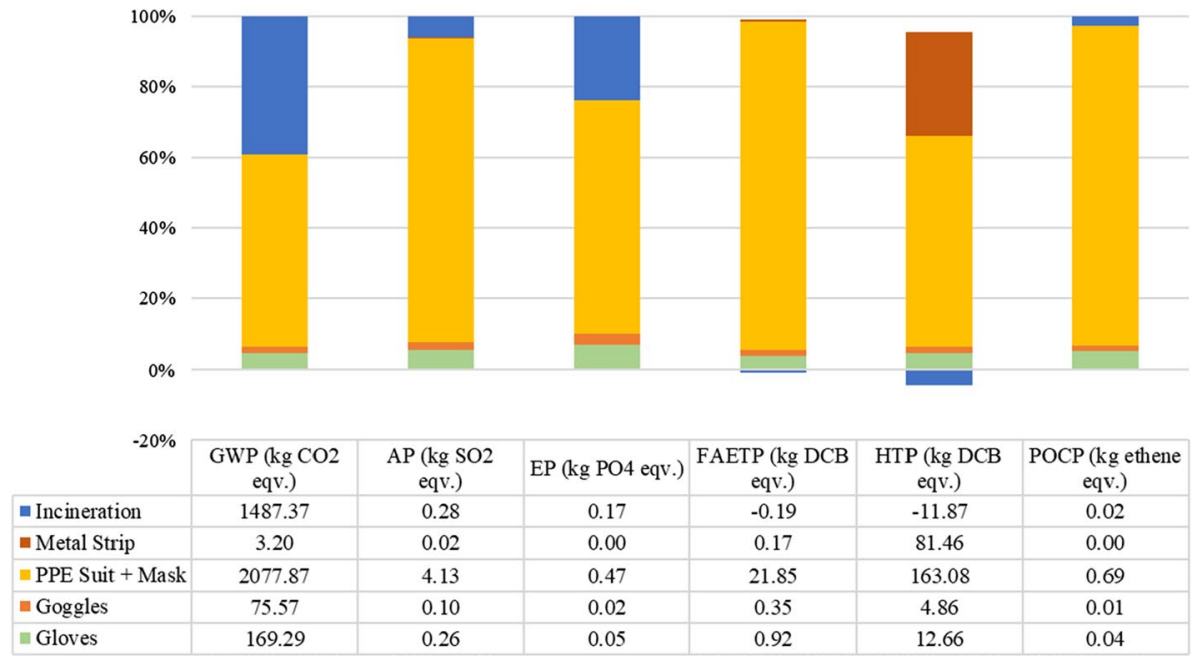

Fig. 5 LCA results for Case-II, Cradle to Grave with Decentralized Incineration

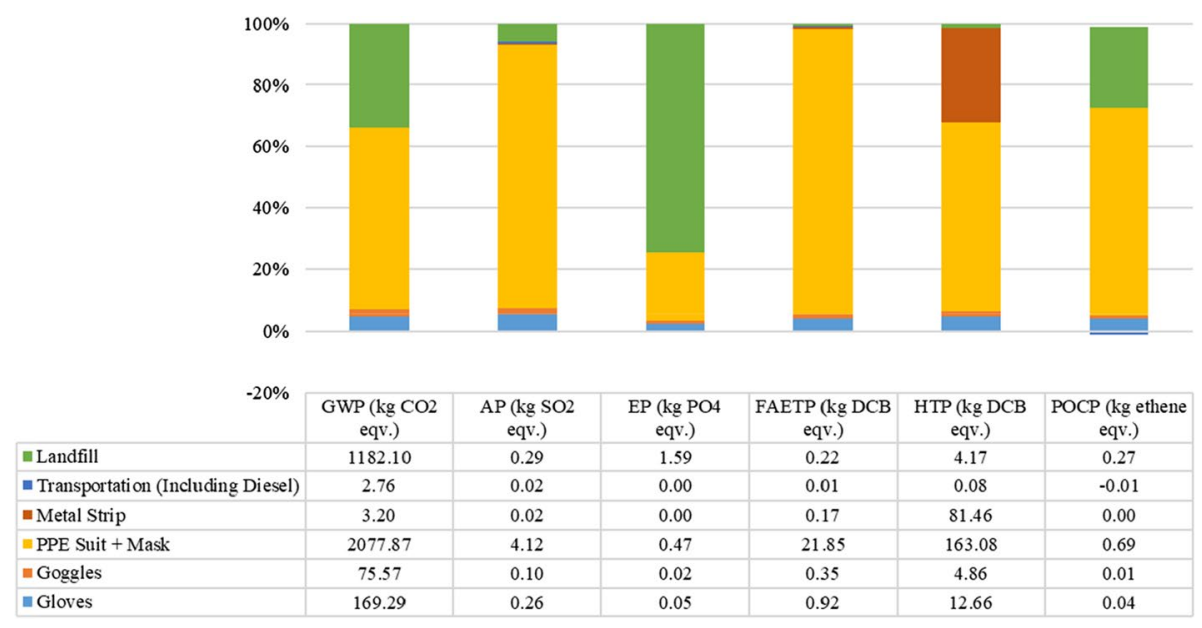

Fig. 6 LCA results for Case-III, Cradle to Grave with Landfill

enemy, the world itself is changing. Behavioural aspects of human beings have changed drastically including, but not limited to, working cycle, working time, personal hygiene, sleep cycle, consumption patterns of goods and services and so on.

With these changing habits, the use of PPEs have increased drastically, especially by medical practitioners, in order to safeguard themselves and humanity from this novel coronavirus. While the use is absolutely essential and justified, it is to be noted that disposal of these PPEs might become a problem in the near future, for which we should finding solutions today. In the current analysis, we have explored various options of disposing of these PPEs through LCA approach. Three cases with different disposal options are considered. Two of them include centralized and decentralized incineration, 
and one is landfill. The complete environmental footprint is considered through the cradle to grave in order to understand the detailed impact magnitude from each of the steps during the life cycle of PPEs. The results are collated and presented in Table 2.

From Table 2, it is evident that decentralized incineration seems to be a viable option for disposal of PPEs both in terms of environment and health. The least viable option is Landfill based disposal with all impact categories on a higher side except for GWP. The decentralized incinerator has a lower footprint in terms of EP, HTP, POCP, and GWP when compared to centralized incinerators. At the same time, it produces almost similar impact in terms of AP and FAETP. Decentralized incinerator is a viable option because of additional reasons as well which are not considered in the scope of these impacts. The centralized incinerator adds number of people handling the PPEs which might be infected by SARS-CoV-2. Right from local disposal to centralized collection facility, there are additional number of people handling the waste and hence have higher chances of contracting the disease which can be avoided if decentralized systems are put in place. Considering the above, it is important to note that LCA impact categories have produced high footprint values for decentralized system as well, hence there is always a need to improve the systems at hand to reduce the overall impacts.

Given the above results, it is important to create strategies of handling such type of wastes in advance given that times are changing fast and policy decisions are to be taken with speed and scientific accuracy to reduce the impact on human lives. The LCA approach in the present work has demonstrated that it can be used as an important tool in such decision making and that environmentally sound and sustainable strategies can be devised using it. Furthermore, in addition to preparing for the future with respect to increase in generation of biomedical waste, there is a need to educate people who are handling it. The pandemic has altered the waste generation dynamics, creating distress among workers involved in sanitation and policymakers. COVID-19 times have shown that microbes can be very deadly if proper hygiene is not followed, and one of the important components of hygiene is the proper handling of waste. While efforts are being made to make people understand the severity of this virus, there is a need to educate and inform these front line workers who are handling this waste as well. The results from the research can be used for decision making to plan future strategies for environmentally sound management of COVID-19 infected PPE waste.

Table 2 Consolidated results for impact assessments of three cases

\begin{tabular}{|c|c|c|c|}
\hline $\begin{array}{c}\text { Impact } \\
\text { categories }\end{array}$ & $\begin{array}{c}\text { Case I: Centralized } \\
\text { incineration }\end{array}$ & $\begin{array}{c}\text { Case-II: Decentralized } \\
\text { incineration }\end{array}$ & $\begin{array}{c}\text { Case III: } \\
\text { Landfill }\end{array}$ \\
\hline $\begin{array}{c}\text { GWP (kg } \\
\mathrm{CO}_{2} \text { eqv.) }\end{array}$ & 3816.1 & 3813.3 & 3510.8 \\
\hline $\begin{array}{c}\mathrm{AP}\left(\mathrm{kg} \mathrm{SO} \text { S }_{2}\right. \\
\text { eqv.) }\end{array}$ & 4.8 & 4.8 & 4.8 \\
\hline $\begin{array}{c}\text { EP (kg PO } \\
\text { eqv.) }\end{array}$ & 0.7 & 0.7 & 2.1 \\
\hline $\begin{array}{c}\text { FAETP (kg } \\
\text { DCB eqv.) }\end{array}$ & 23.1 & 23.1 & 23.5 \\
\hline $\begin{array}{c}\text { HTP (kg } \\
\text { DCB eqv.) }\end{array}$ & 250.3 & 250.2 & 266.3 \\
\hline $\begin{array}{c}\text { POCP (kg } \\
\text { Ethene eqv.) }\end{array}$ & 0.8 & 0.8 & 1.0 \\
\cline { 2 - 4 } & \multicolumn{3}{|c|}{ Colour Range indicating Impact Magnitude } \\
\cline { 2 - 4 } & \multicolumn{2}{|c|}{ High Medium } & Low \\
\hline
\end{tabular}


Acknowledgements The authors greatly acknowledge the support of Council of Scientific and Industrial Research (CSIR) and Director, CSIR-NEERI under the major laboratory Project Number MLP-162. The manuscript is checked for plagiarism using licensed version of iThenticate software with assigned manuscript Reference Number as CSIR-NEERI/KRC/2020/JULY/CSUM-DRC-ERMD-DIR/1 dated 04 July 2020.

\section{References}

Abhimanyu C. (2020). Fighting from the bottom, India's sanitation workers are also frontline workers battling Covid. Retrieved June 252020 https://indianexpress.com/article/india/india-sanitation-workerswaste-pickers-coronavirus-pandemic-6414446/.

ACR (2020). Municipal waste management and COVID-19. Retrieved June 23, 2020 from https://www. acrplus.org/en/municipal-waste-management-covid-19.

Aggarwal, M. (2020). Pollution watchdog releases guidelines to handle COVID-19 biomedical waste. Retrieved June 30, 2020 from https://india.mongabay.com/2020/03/pollution-watchdog-releases-guide lines-to-handle-covid-19-biomedical-waste/.

Agrawal, S., \& Jadon, S. S. (2018). Decentralized waste management: Analysis for residential localities of Gwalior City. International Research Journal of Engineering and Technology (IRJET), 5(6), 2366-2370.

Arcadis (2017). Solid waste management for Nagpur, feasibility study_United Nations. Retrieved June 26, 2020 from https://www.unescap.org/sites/default/files/Report_IN_Nagpur_SolidWasteManagement _ArcadisGermanyGmbH_2017.pdf.

Babu, G. L. S., Lakshmikanthan, P., Santhosh, L. G. (2014). Life cycle analysis of municipal solid waste (MSW) land disposal options in Bangalore City. In Creating infrastructure for a sustainable world (pp. 795-806).

Bherwani, H., Gupta, A., Anjum, S., Anshul, A., Kumar, R. (2020a). Exploring dependence of COVID-19 on environmental factors and spread prediction in India. npj Clim Atmos Sci, 3, 38 (2020). https://doi. org/10.1038/s41612-020-00142-x.

Bherwani, H., Nair, M., Musugu, K., et al. (2020b). Valuation of air pollution externalities: Comparative assessment of economic damage and emission reduction under COVID-19 lockdown. Air Quality, Atmosphere and Health. https://doi.org/10.1007/s11869-020-00845-3.

Bherwani, H., Nair, M., Kapley, A., \& Kumar, R. (2020c). Valuation of ecosystem services and environmental damages: An imperative tool for decision making and sustainability. European Journal of Sustainable Development Research, 4(4). https://doi.org/10.29333/ejosdr/8321.

Boškoski, I., Gallo, C., Wallace, M. B., \& Costamagna, G. (2020). COVID-19 pandemic and personal protective equipment shortage: protective efficacy comparing masks and scientific methods for respirator reuse. Gastrointestinal Endoscopy.

COVID-19 Dashboard by the Center for Systems Science and Engineering (CSSE) at Johns Hopkins University (JHU), ArcGIS. Johns Hopkins University. Retrieved June 16, 2020 from https://gisanddata .maps.arcgis.com/apps/opsdashboard/index.html\#/bda7594740fd40299423467b48e9ecf6.

CPCB (2017) - Annual progress report: CPCB ENVIS Centre on control of pollution (Water, Air, \& Noise). Retrieved June 30, 2020 from https://www.cpcbenvis.nic.in/envis_annual_report/Annual\%2520progre ss\%2520report\%25202016-17.pdf.

CPCB (2020). Guidelines for handling, treatment and disposal of waste generated during treatment/diagnosis/ quarantine of COVID-19 Patients-Revision 2. Retrieved June 27, 2020 from https://tnpcb.gov.in/ pdf_2020/BMW-GUIDELINES-COVID_Revisied_April2020.pdf.

CPCB Revision (2020). Guidelines for handling, treatment and disposal of waste generated during treatment/diagnosis/ quarantine of COVID-19 Patients. Retrieved July01, 2020 from https://ncdc.gov.in/ WriteReadData/1892s/63948609501585568987.pdf.

Desai, S. R., Kovarik, C., Brod, B., James, W., Fitzgerald, M. E., Preston, A., et al. (2020). COVID-19 and personal protective equipment: Treatment and prevention of skin conditions related to the occupational use of personal protective equipment. Journal of the American Academy of Dermatology, 83(2), 675-677.

Design Life Cycle (2018). Nitrile gloves: A life cycle assessment. Retrieved June 20, 2020 from https:// www.designlife-cycle.com/life-cycle-of-nitrile-rubber-gloves.

Draft NERP (2019). Retrieved June 29, 2020 from https://www.iastoppers.com/20th-august-2019-currentaffairs-analysis-iastoppers/draft-national-resource-efficiency-policy-nerp-2019/. 
Gupta, A., Bherwani, H., Gautam, S., et al. (2020). Air pollution aggravating COVID-19 lethality? Exploration in Asian cities using statistical models. Environment, Development and Sustainability. https://doi. org/10.1007/s10668-020-00878-9.

Halyard: Protective apparel catalog. Retrieved June 22, 2020 from https://www.halyardhealth.com/media /188238/c14173_protective-_apparel_catalog.pdf.

Healthline 2020. Here's exactly where we are with vaccines and treatments for COVID-19. Retrieved August 262020 from https://www.healthline.com/health-news/heres-exactly-where-were-at-with-vacci nes-and-treatments-for-covid-19.

Henam, S., \& Shrivastav, R. (2019).Biomedical waste management in India: Still a looming concern. Retrieved June 30, 2020 from https://www.downtoearth.org.in/blog/health/biomedical-waste-manag ement-in-india-still-a-looming-concern-63896.

Herron, J. B. T., Hay-David, A. G. C., Gilliam, A. D., \& Brennan, P. A. (2020). Personal protective equipment and Covid 19-a risk to healthcare staff? British Journal of Oral and Maxillofacial Surgery, 58(5), $500-502$.

Hindustan times (2020). 548 doctors, nurses, paramedics infected with Covid-19 across India. Retrieved May 06, 2020 from https://www.hindustantimes.com/india-news/548-docs-nurses-paramedics-infec ted-with-covid-19-across-india-report/story-o2pM3w2adM4g3PXI6TBlkN.html.

Holland, M., Zaloga, D. J., \& Friderici, C. S. (2020). COVID-19 Personal Protective Equipment (PPE) for the emergency physician. Visual journal of emergency medicine, 19, 100740.

ICT (2008). US Pandemic could severely strain face mask, other PPE supply pipeline. Retrieved June 29, 2020 from https://www.infectioncontroltoday.com/view/us-pandemic-could-severely-strain-face-maskother-ppe-supply-pipeline.

Italy WWF (2020). In the disposal of masks and gloves, responsibility is required WWF International. Retrieved June 8, 2020 from https://www.wwf.it/chi_siamo/organizzazione/.

Ivy S. (2020). How the plastic industry is exploiting anxiety about COVID-19. Retrieved May 21, 2020 from https://www.greenpeace.org/usa/how-the-plastic-industry-is-exploiting-anxiety-about-covid-19/.

Jachowicz, M. (2013). Electrostatic properties of selected personal protective equipment regarding explosion hazard. Journal of Sustainable Mining, 12(1), 27-33.

Jeswani, H. K., \& Azapagic, A. (2016). Assessing the environmental sustainability of energy recovery from municipal solid waste in the UK. Waste Management, 50, 346-363.

Jinadatha, C., Simmons, S., Dale, C., Ganachari-Mallappa, N., Villamaria, F. C., Goulding, N., et al. (2015). Disinfecting personal protective equipment with pulsed xenon ultraviolet as a risk mitigation strategy for health care workers. American journal of infection control, 43(4), 412-414.

Jiri, J. K., Klemes, J., Fan, Y. V., Tan, R. R., \& Jiang, P. (2020). Minimizing the present and future plastic waste, energy and environmental footprints related to COVID-19. Renewable and Sustainable Energy Reviews, 127, 109883.

Justine C. (2020). The COVID-19 pandemic is generating tons of medical waste. Retrieved June 18, 2020 from https://www.theverge.com/2020/3/26/21194647/the-covid-19-pandemic-is-generating-tons-ofmedical-waste.

Kaur, S., Bherwani, H., Gulia, S., Vijay, R., \& Kumar, R. (2020). Understanding COVID-19 transmission, health impacts and mitigation: timely social distancing is the key. Environment, Development and Sustainability, 1-17. https://doi.org/10.1007/s10668-020-00884-x.

Klemeš, J. J., Van Fan, Y., Tan, R. R., \& Jiang, P. (2020). Minimising the present and future plastic waste, energy and environmental footprints related to COVID-19. Renewable and Sustainable Energy Reviews, 127, 109883.

Marcin, J. (2013). Electrostatic properties of selected personal protective equipment regarding explosion hazard. Journal of Sustainable Mining, 12(1), 27-33.

MoHFW (2020). Advisory on reprocessing and re-use of eye protection-Goggles. Retrieved June 28, 2020 from https://www.mohfw.gov.in/pdf/Advisoryonreprocessingandreuseofeyeprotectiongoggl es.pdf.

Nair, M. M., Bherwani, H., Kumar, S., Gulia, S., Goyal, S. K., \& Kumar, R. (2020). Assessment of contribution of agricultural residue burning on air quality of Delhi using remote sensing and modelling tools. Atmospheric Environment, 230, 117504.

New India Express (2020). Sanitation workers, attendants most vulnerable to Covid-19 among hospital staff: AIIMS study. Retrieved August 10, 2020 from https://www.newindianexpress.com/natio n/2020/aug/10/sanitation-workers-attendants-most-vulnerable-to-covid-19-among-hospital-staff -aiims-study-2181595.html.

New York Times. (2020). Is the world ready for the coronavirus? Distrust in science and institutions could be a major problem if the outbreak worsens. Retrieved May 29, 2020 from https://www.nytim es.com/2020/01/29/opinion/coronavirus-outbreak.html. 
NMPA (2020) - State council issues guideline on regular COVID-19 prevention. Retrieved May 28, 2020 from https://subsites.chinadaily.com.cn/nmpa/2020-05/09/c_487513.htm.

PAHO (2020). Requirements and technical specifications of personal protective equipment (PPE) for the novel coronavirus (2019-ncov) in healthcare settings. Retrieved June 26, 2020 from https://iris. paho.org/handle/10665.2/51906?show=full.

Park, C. et al. (2020). Global shortage of personal protective equipment amid COVID-19: Supply chains, bottlenecks, and policy implications. ADB Briefs. Retrieved from http://dx.doi.org/https://doi. org/10.22617/BRF200128-2

Parkes, O., Lettieri, P., \& Bogle, D. L. (2015). Life cycle assessment of integrated waste management systems for alternative legacy scenarios of the London Olympic Park. Waste Management, 40, 157-166.

Prayag A. (2020). As Covid-19 cases in district surge, so does the quantity of biomedical waste. Retrieved June 26, 2020 from https:/www.hindustantimes.com/gurugram/as-covid-19-cases-in-district-surge-sodoes-the-quantity-of-biomedical-waste/story-UljEKpYXIWX5CEx4LBRUUP.html.

Priyadarshini, R., Jafrin, L., Aravinthan, A., \& Sivagnanam, G. (2020). Rationing PPEs during a pandemic: The COVID-19 scenario. Research in Social \& Administrative Pharmacy.

Rejane, R. M., Zortea, R., Carlos, A. M. M., \& Modolo, R. C. E. (2019). Suggestion of life cycle impact assessment methodology: Selection criteria for environmental impact categories. New Frontiers on Life Cycle Assessment-Theory and Application. https://doi.org/10.5772/intechopen.83454.

Ringenberg, K. R., Fremming, B. A., Lisco, S. L., \& Schulte, T. E. (2020). Protection of anesthesia providers from silent carriers of COVID-19 while minimizing disposable PPE utilization. Journal of clinical anesthesia, 66, 109930.

Rowan, N. J., \& Laffey, J. G. (2020). Challenges and solutions for addressing critical shortage of supply chain for personal and protective equipment (PPE) arising from Coronavirus disease (COVID19) pandemic-Case study from the Republic of Ireland. Science of The Total Environment, 138532.

Satheesh, S. (2020). Coronavirus: Mumbai waste collectors work with their bare hands. Retrieved June30, 2020 from https://www.aljazeera.com/news/2020/03/coronavirus-mumbai-waste-collectors -work-bare-hands-200326043754117.html.

Seemal, R. D., Kovarik, C., Brod, B., James, W., et al. (2020). COVID-19 and personal protective equipment: Treatment and prevention of skin conditions related to the occupational use of personal protective equipment. Journal of the American Academy of Dermatology. https://doi.org/10.1016/j. jaad.2020.05.032.

Selvakumar, K., et al. (2020). Hospital preparedness for emergency in India (Hope-I) to combat Covid19 outbreaks. Studies in Indian Place Names, 40(70), 4226-4236.

Tabah, A., Ramanan, M., Laupland, K. B., Buetti, N., Cortegiani, A., Mellinghoff, J., et al. (2020). Personal protective equipment and intensive care unit healthcare worker safety in the COVID-19 era (PPE-SAFE): An international survey. Journal of Critical Care.

The conversation (2020). Healthcare is still hooked on single-use plastic PPE, but there are more sustainable options. Retrieved August 7, 2020 from https://theconversation.com/healthcare-is-still -hooked-on-single-use-plastic-ppe-but-there-are-more-sustainable-options-143940.

The Guardian (2020). Global report: India reports surge in Covid-19 cases as lockdown eased. Retrieved June 28, 2020 from https://www.theguardian.com/world/2020/jun/11/global-report-india-reports-surge -in-covid-19-cases-as-lockdown-eased.

The New York Times (2020). Your used mask needs to make it to the trash can. Retrieved July 25, 2020 from https://www.nytimes.com/2020/07/25/climate/covid-masks-discarded.html.

UNEP (2020). Working with the environment to protect people UNEP's COVID-19 response. Retrieved June 29, 2020 from https://wedocs.unep.org/bitstream/handle/20.500.11822/32218/UNEP_COVID .pdf? sequence $=1 \&$ is Allowed $=\mathrm{y}$.

Vanapalli, K. R., Sharma, H. B., Ranjan, V. P., Samal, B., Bhattacharya, J., Dubey, B. K., et al. (2020). Challenges and strategies for effective plastic waste management during and post COVID-19 pandemic. Science of The Total Environment, 750, 141514.

Virginijus S. (2020). Waste management in the context of the coronavirus crisis. Retrieved June 26, 2020 from https://ec.europa.eu/info/sites/info/files/waste_management_guidance_dg-env.pdf.

WHO (2017) - Report on health-care waste management status in countries of the South-East Asia Region. Retrieved June 29, 2020 from https://apps.who.int/iris/handle/10665/258761.

Wathore, R., Gupta, A., Bherwani, H., \& Labhasetwar, N. (2020). Understanding air and water borne transmission and survival of coronavirus: Insights and way forward for SARS-CoV-2. Science of The Total Environment, 749, 141486.

WHO (2017). Safe management of wastes from health-care activities: A summary. Retrieved August 28, 2020 from http://apps.who.int/bookorders.\%0Ahttp://apps.who.int/iris/bitstream/10665/259491/1/ WHO-FWC-WSH-17.05-eng.pdf?ua=1. 
WHO (2020). Coronavirus disease (COVID-19) advice for the public: MythBusters. Retrieved August 28, 2020 from https:/www.who.int/emergencies/diseases/novel-coronavirus-2019/advice-forpublic/ mythbusters?gclid=Cj0KCQjws536BRDTARIsANeUZ59tJAgWIXfLL33sdO3yX7BVOhqC6nbfoEJP PNLnoyatEmF_NObtShoaAh5pEALw_wcB\#medicines.

WHO (2020a) - Statement regarding cluster of pneumonia cases in Wuhan, China. Retrieved June 9, 2020 from https://www.who.int/china/news/detail/09-01-2020-who-statement-regarding-cluster-of-pneum onia-cases-in-wuhan-china.

WHO (2020b) - Report: Laboratory testing of human suspected cases of novel coronavirus (nCoV) infection. Retrieved June 10, 2020 from https://apps.who.int/iris/bitstream/handle/10665/330374/WHO2019-nCoV-laboratory-2020.1-eng.pdf.

WHO (2020c) - Coronavirus disease (COVID-19) advice for the public. Retrieved May 12, 2020 from https ://www.who.int/emergencies/diseases/novel-coronavirus-2019/advice-for-public.

WHO (2020d) - Rational use of personal protective equipment for coronavirus disease (COVID-19) and considerations during severe shortages. Retrieved May 18, 2020from https://www.who.int/publicatio ns/i/item/rational-use-of-personal-protective-equipment-for-coronavirus-disease-(covid-19)-and-consi derations-during-severe-shortages.

WHO (2020e). Retrieved June 29, 2020 from https://www.who.int/dg/speeches/detail/who-director-generals-opening-remarks-at-the-media-briefing-on-covid-19---3-march-2020.

Worldometer (2020). Retrieved July 1, 2020 from https://www.worldometers.info/world-population/india -population/.

Yahoo (2020). As coronavirus cases surge, Ahmedabad hospitals shell Out Rs 45/kg for disposal of Covid19 Bio-waste. Retrieved June 20, 2020 from https://in.news.yahoo.com/coronavirus-cases-surge -ahmedabad-hospitals-061800880.html.

Zero Waste (2020a). FAQ on COVID-19 and zero waste. Retrieved June 18, 2020 from https://zerowastee urope.eu/wp-content/uploads/2020/05/2020_05_27_zwe_faq_covid19.pdf.

Zero Waste $(2020 \mathrm{~b})$. Zero waste Europe statement on waste management in the context of COVID-19. Retrieved June 22, 2020 from https://zerowasteeurope.eu/2020/04/zero-waste-europe-statement-onwaste-management-in-the-context-of-covid-19/.

Publisher's Note Springer Nature remains neutral with regard to jurisdictional claims in published maps and institutional affiliations.

\section{Affiliations}

\section{Harender Kumar ${ }^{1} \cdot$ Amaanuddin Azad $^{1} \cdot$ Ankit Gupta $^{1,2} \cdot$ Jitendra Sharma ${ }^{3}$. Hemant Bherwani ${ }^{1,2} \mathbb{D} \cdot$ Nitin Kumar Labhsetwar ${ }^{1,2} \cdot$ Rakesh Kumar $^{1,2}$}

1 CSIR-National Environmental Engineering Research Institute, CSIR-NEERI, Nagpur, Maharashtra 440 020, India

2 Academy of Scientific and Innovative Research [AcSIR], Ghaziabad, Uttar Pradesh 201 002, India

3 United Nations Environment Programme, New Delhi 110 003, India 